\title{
Liberty in Harmony: An Integration of Confucian Harmony and Liberalism in Contemporary China
}

\author{
Mei Yang
}

\begin{abstract}
As the mainstream ideology, Confucian harmony deeply influences ways of thinking and social life in the East. Contemporary China has experienced quite a radical change since the Xīnhài Revolution in 1911. It also marked the re-examination of Confucianism, i.e. the development of New Confucianism. New Confucianism needs to encourage China to fit the modern and global context. Therefore, the revival of Confucian harmony must remake itself to fit the modern world. A certain degree of convergence between Confucian harmony and liberalism, the mainstream ideology in the West, is necessary. Personal improvement is a hotly disputed idea among Chinese Confucians and Western liberals because transformation of public ethics is closely related to transformations of the self. This paper argues the importance of integration between harmony and liberalism. What is important is to explore how each tradition can shed light on theoretical and practical issues regarding harmony between the individual and the community, rather than individual sovereignty over communal claims in ideological studies.
\end{abstract}

Keywords: ideology, harmony, liberalism, China

Mei Yang. "Liberty in Harmony: An Integration of Confucian Harmony and Liberalism in Contemporary China." In Vienna Journal of East Asian Studies, Volume 7, eds. Rudiger Frank, Ina Hein, Lukas Pokorny, and Agnes SchickChen. Vienna: Praesens Verlag, 2015, pp. 227-245.

https://doi.org/10.2478/vjeas-2015-0008 


\section{Introduction}

Transformation of public ethics is closely related to transformations of the self. China's modernisation has resulted in the decline of its traditional patriarchal society, and the growth of egocentricity. During this process, the Cultural Revolution (19661976) left a faith vacuum in the minds of the Chinese people, and rapid economic development in the past thirty years has brought economic prosperity but has maximised materialism. Commercialism, consumerism, nihilism, and mammonism have been popularised. As a result of this moral and spiritual crisis, the self - traditionally perceived as part of the clan genealogy and family continuity - becomes alienated as an atom-like individual without public virtues ( $\mathrm{Li} 2013: 3$ ). In an environment where religious ethics and pressure from a moral public are absent, such a 'self' is lost, resulting in a morally out-of-control situation.

The solutions are elusive and complex. Punishment is often perceived as axing the branch rather than the root. Human beings are fully aware of the influence of moral values which the effectively contributes to their wellbeing; morality is the core concept of any moral system. Within this context, the revival of Confucianism began. Contemporary Chinese society needs strong values to structure its ethical orientation. We need to urgently rethink the moral and spiritual doctrines in Confucian discourse. Reconstruction of Confucian harmony is, therefore, progressive in the current social climate.

In so doing, we need to re-evaluate and re-examine the doctrine of 'harmony' in Confucianism, and to uncover its significance. This doctrine must successfully remake itself in such a context so as to express the core commitment of individuals to collective morality. Furthermore, to reconcile Confucian harmony with Western liberalism can be seen as a progressive application of theory in a global context. A lack, or ignorance, of the common ground between these two ideologies will lead to irreconcilable clashes between those with incompatible interpretations.

This paper firstly attempts to interpret harmony as espoused in selected Confucian texts, and then briefly traces the origin and development of the thinking and theory of liberalism in the West. Thereafter it contextualises them in their specific historical, socio-political and cultural environments. The paper highlights how each tradition can shed light on theoretical and practical issues in the study of ideology, specifically regarding harmony between the individual and the community as a means of achieving personal development. 


\section{The Historical Development of Harmony}

\section{A Brief Introduction to Confucianism}

Confucianism has been applied to philosophical and ethical teachings, a tradition of scholarship, a religion, a social ethic and a state ideology (Makeham 2003: 1). Confucianism evolved from the Shāng-Zhōu 商周 culture, was founded by Confucius (Kŏngž 孔子,tr. 551-479 BCE) during the Spring and Autumn period, and was reshaped by Mencius (Mèngž 孟子, tr. 371-289 BCE) and Xúnž́ 荀子(tr. 298-230 BCE) during the Warring States period. ${ }^{1}$ Confucianism gained its eminence during the Hàn Dynasty 漢朝 (206BCE-220CE). Impetus developed among scholars in the Song Dynasty 宋朝 (960-1279)to re-examine the Confucian tradition after the Hàn Dynasty, and this gave Confucianism a new direction, namely Neo-Confucianism. There are three traditions of thought that can be traced as the main sources of NeoConfucianism: Confucianism; Buddhism, together with Daoism via the medium of Chán Buddhism; and Daoist religion. Neo-Confucianism came to be divided into two main schools. The first is Lixué 理學, or the School of Principle, pioneered by Chéng Yí 程頣 (1033-1107) and completed by Zhū Xī 朱喜 (1130-1200); the other is Xīnxué 心學, or the School of Mind, initiated by Chéng Hào 程影 (1032-1085), continued by Lù Xiàngshān 陸象山 (1139-1193) and completed by Wáng Shǒurén 王守仁 (1472-1528).

Confucianism was taken as the founding ideology of the feudal, monarchical system in mainland China. The twentieth century had seen a decline in Confucian morality due to the denigration of traditional Chinese culture. In 1915 Chinese intellectuals inaugurated a 'New Culture Movement' that sought fundamental changes to Chinese values, practices, and even the Chinese language (Angle 2012: 3). Confucianism had lost its traditional strength in its homeland (Fan 1999: 1). Nowadays, there is a trend to revive Confucianism in contemporary China.

\section{The Substance of Harmony in Confucian and Daoist Thought}

Confucians believe that it is by self-cultivation and the instruction of sages that humans come into harmony with heaven (Yao 2000: 229). Daoism teaches that the only way to harmony is to follow natural law through the process of cultivating human nature.

Heaven (tiān 天) plays a prominent role in Confucianism and Daoism. Tiān has multiple meanings - including a range of uses running from the most to the least

1 The Spring and Autumn period (722-481 BCE) and the Warring States period (480-221 BCE) are two subperiods within the Eastern Zhōu. 
anthropomorphic - and is characterised by a man who is inspired by a profound sense of mission to help human beings to live in accordance with the guiding intelligence of the cosmos (Creel 1932: 64; cf. Louden 2002: 77). Already in Shāng 商 (tr. 1600-1046 BCE) civilisation we see the characteristic Chinese interrelatedness of respect for ancestors, ritual activity, and political power (van Norden 2002: 4). In the Western Zhōu 西周 dynasty (tr. 1046-771 BCE), the Duke of Zhōu (Zhōu Gōng 周 公) argued that because the last ruler of the Shāng was corrupt and cruel to his people, heaven (tiān) had taken the mandate to rule (ming 命) away from the Shāng king (Zhòu 紂) and had given it to the virtuous Zhou rulers. This doctrine became the basis of Chinese political thought for the next three millennia (van Norden 2002: $5)$.

Confucius and his disciples elaborated on the meaning and functions of harmony and believed that among all the things that can be achieved through ritual, harmony is most valuable (Analects [Lúnyǔ 論語] $]^{2}$ 1: 12; cf. Yao 2000: 172).

In Daoism, to achieve universal order is to blend the Supreme Ultimates into harmony. As the Dàodéjing states, 'The ten thousand things carry yin 陰 on their backs and wrap their arms around yáng 陽. Through the blending of qi 氣 they arrive at a state of harmony ${ }^{3}$ (Dàodéjing 道德經 ${ }^{4}: 42$ cf. Lai 2001: 101). Here the yin/yáng distinction corresponds to two Supremes - contrasting but mutually conditioning elements - and the two complementary opposites are in dynamic balance. Tàiji 太極 (Figure 1), the ancient Chinese diagram of yìn and yáng, shows the two fundamental energy forces in interlocking harmony.

Yìn and yáng constitute the rhythm of the dào 道 (Moeller 2006: 36) and this is the best-known symbol of Chinese thought. The dào is defined as 'an abstract, indescribable force, never anthropomorphised' (Kleeman 2001: 62) that underlies everything. Existence is perceived inclusively as a harmonious collection of complementary opposites - the emphasis is on the whole and not on the parts (Reid and Evangeliou 2008: 341). Qi is a sort of general or universal 'medium'-it is not only in 'nature' but also in works of art, houses and gardens, interpersonal relations, and emotions. It is also important in warfare (Moeller 2006: 37). Qi has internal dynamic correlational forces and coalesces into the Five Phases (wǔxing 五行), ${ }^{5}$ which form all things of which reality is composed. It is both explicitly and subtly expressed in various temporal-spatial, tangible, and intangible forms. The ancient cosmology of harmony has always been an unwritten rule guiding almost all aspects of social and

2 The Analects (Lúnyŭ) is a collection of sayings, brief discussions and observations by and about Confucius, his disciples and his contemporaries. 'Analects' is an obscure English word used in general as a translation of the Lúnyŭ, which means 'selected sayings' (van Norden 2002: 13). The Analects, together with works of subsequent Confucian thinkers such as Mencius, form Confucianism, and therefore lie at the core of Chinese culture (Luo 2010: 776).

3 萬物負陰而抱陽。沖氣以為和。Wànwù fù yīn ér bào yáng, chōng qì y̌̀ wéi hé.

4 Dàodéjīng is the ancient Daoist classic which has a canonical status in many Daoist traditions.

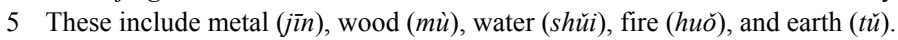


personal life. It is the 'one character that holds the clues of everything' (Luo 2010: 775). ${ }^{6}$ Luo further states that

It is the mutual harmony of these contrasting elements that produces aesthetic beauty in Chinese cultural and social constructions, and where peace finds its way in reconciling opposing and conflicting ideas (ibid.: 776).

From $202 \mathrm{BCE}$ to about $9 \mathrm{CE}$, Confucian intellectuals were thoroughly engaged in the exchange and synthesis of ideas with other worldviews, with the Daoist concept of harmony becoming an important concept in Neo-Confucianism.

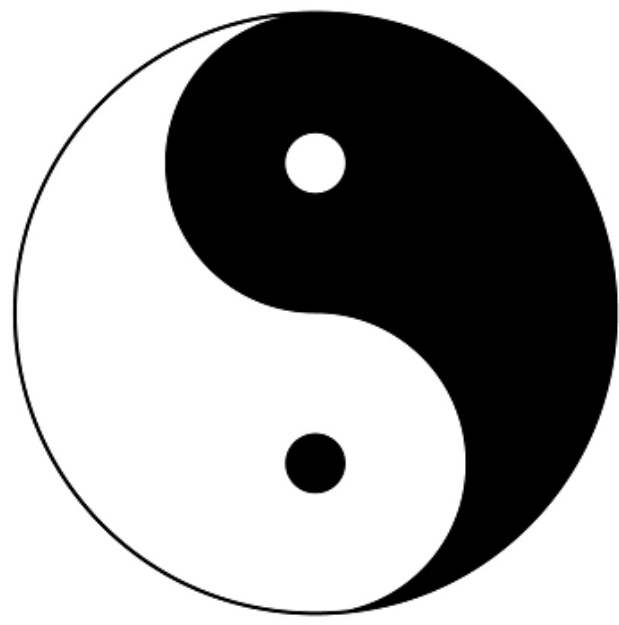

Figure 1 Tàijí (the white is yang and the black is yīn)

\section{The Philosophical Value of Harmony}

The important Confucian work The Great Learning (Dàxué) provides in a nutshell the idea of harmony. It is one of the best sources for the Neo-Confucian emphasis on self-cultivation. The essence of the Dàxué is moral self-cultivation through 'eight steps of cultivation' to achieve harmony and peace among communities and nations (Keenan 2011: 40).

The notion of harmony also finds its cogent, canonical status defined in The Doctrine of the Mean (Zhōngyōng 中庸). The first section of Zhōngyōng teaches that

6 From the BBC live broadcast of the opening ceremony of the Běijīng Olympics. 
what follows from the balanced and measured play of the emotions in the mind-heart is harmony. Conflict has its causes in one's own heart and mind, and harmony is a reflection of one's inner peace. Once the heart and mind are at peace, one can have a harmonious relationship with other people, nature, and heaven.?

As the 'highest virtue', harmony is said to be necessary for the peaceful life of individuals, the family, and the state. Order and peace must be cultivated internally and externally.

It is to misunderstand harmony if we consider it as a constant claim for the status quo and in opposition to change. Harmony is regarded, on the contrary, as a result of constant change and the resolution of conflict. In this sense, the concept of harmony itself contains both conflict and its resolution, and the Confucian way of harmony indicates not only the need for adjustment and refinement but also the need to overcome tension (Yao 2000: 178). Harmony is not in opposition to critique, but rather it is a different way to resolve conflicts. Consolidating and resolving conflicts based on mass collective values is the main procedure of critique within the parameters of harmony.

Humans are developing a unified and common resolve to prepare for the coexistence of different cultures and different nations. The Confucian tradition can make a contribution to the unity and harmony of all-under-heaven (tiānxià yìjiā 天下一家). As Fang and Li suggest

The return to the root of the Chinese spirit of humanism will be enough to be the foundation of its innovation, and will enable it to make a contribution to the Western world (Fang and Li 1995 vol. 3: 308).

\section{Implementing Harmony through New Confucianism in Contemporary China}

Confucianism has spread throughout East Asia including China, Japan, Korea, and Vietnam. Given the purpose of this paper, the discussion of harmony will be confined to New Confucianism in contemporary China. After the May Fourth Movement in 1919, Confucianism in mainland China had been targeted 'derogatively by some as a catchall term subsuming all that is rotten in China's feudal past' (Makeham 2003: 1). Harmony was completely replaced by radical class conflict and social disharmony during the Cultural Revolution, which proved to be a disaster. Reexamination of Confucianism started in 1912. Littlejohn observes that

7 喜、怒、哀、樂之未發、謂之中。發而皆中節、謂之和。中也者、天下之大本也。和也者、天下之 達道也。致中和、天地位焉、萬物育焉。Xì, nù, ài, lè, zhī wèi fā, wèi zhī zhōng. Fā ér jiē zhōng jié, wèi zhī hé. Zhōng yě zhě, tiānxià zhī dàběn yě. Hé yě zhě, tiānxià zhī dádào yě. Zhì zhōnghé, tiāndì wèi yān, wànwù yùyān. 
Confucianism has negotiated the impact of Western traditions, overcome well-organised efforts to exterminate it, and grown into a new and vibrant form known as New Confucianism (Littlejohn 2011: 175).

New Confucianism can be understood as Confucianism attempting to remake itself in the modern world. The revival and popularisation of Confucianism in contemporary China has many sources. Makeham describes how '[It] boasted distinct phases of internal development, a cohort of representative thinkers, and clearly defined lineages of intellectual transmission' (Makeham 2003: 2). Among these thinkers, Liáng Shùmíng 梁漱溟 (1893-1988) believed 'harmonization of all elements of existence' was in the concept of humaneness (cf. Berthrong 1998: 185). Móu Zōngsān 牟宗三 (1909-1995) was another thinker who became central to the very notion of what New Confucianism is. Xióng Shíli 熊十力 (1885-1968) sought to revive the idealistic wing of the Confucian tradition.

Discourse on New Confucianism can be traced precisely to 1986 in Mainland China, when it was identified and funded as a key research topic under the national seventh Five-Year Plan for the social sciences. The revival of Confucianism has since intensified.

We must be aware that mainland China's New Confucianism is still in a process of maturation (Wang 2011: 36). Some scholars in mainland China want to reexamine both the classical and Neo-Confucian texts against the background of modern Western philosophy. Others believe it should be studied only within the context of Chinese culture, because the standard Western philosophical fields distort Confucian writings (Keenan 2011: xiii). Moreover, there are also voices in New Confucianism who wish to make it one of the state religions and scholarly traditions. There is a worry that acceptance of liberal democracy will push China to be completely 'Westernised.' For instance, Kāng Xiăoguāng 康曉光 (2006) focuses on the relationship between state politics, the transformation of social structure, and Confucianism's contribution in the future. Jiăng Qìng 蔣慶, who coined the terms 'Mind Confucianism' and 'Political Confucianism', also insists that Political Confucianism should not adopt Western democracy (see Jiang 2011).

The Chinese are now attempting to reconstruct the ideology of harmony with regard to its values for modern life. The doctrine of harmony is taken in modern society to be the underlying principle of all relationships; harmony is the reason why all virtues can be fully realised (Yao 2000: 173). As a consequence, harmony can be associated with the concept of mass 'unity,' that is, of political and social conformity with an ideology. In this case, 'harmony' can be seen not simply as a benign ethical or aesthetic principle but as part of a power structure (Chilton et al. 2010: 499).

Contemporary China endeavours to rediscover and explore the theme of harmony in the Confucian tradition. Harmony again emerged in the twenty-first century as a discourse of domestic value, namely 'harmonious society' (héxié shèhui 和諧社會), 
and its foreign policy alter ego 'harmonious world' (héxié shijiè 和諧世界) have become the defining discourses of the Chinese Communist Party (CCP). The concept of 'China Dream' (zhōngguó mèng 中国梦) outlined by Chairman Xí Jìnpíng 习近平 (b. 1953) has also promoted the philosophy of harmony as one of the core socialist values (shèhuì zhüyì héxīn jiàzhíguān 社会主义核心价值观).

Thus far the ideology of harmony has been explained in three ways: as a tradition of Chinese philosophical thought, as a social norm, and as a political discourse. The ideology of harmony in contemporary China is a double-edged sword: democratic harmony builds on the values and ethics entrenched in ancient Chinese culture and persisting in modern life, whilst oppressive harmony can only lead to dictatorship. The idea of moral power was one way to harmony, according to Confucius and Mencius. However, the standard and the limits of moral power should be clarified, for any 'power' without limits can lead to subjugation. Contemporary China has to solve the imbalance between economic development and moral reconstruction. How to consolidate and resolve these conflicts is an important task for the way of 'harmony' in New Confucianism in contemporary China. Harmony between morality and materiality may be of the highest importance.

\section{The Ideology of Liberalism}

Liberalism can be traced back to the Enlightenment and beyond. Due to the space restrictions of this paper, this section cannot give the whole history of liberalism and its large family tree, but rather must focus only on its essential ideas.

\section{Early Liberalism}

The term 'liberal' has been in use since the fourteenth century, but has had a wide variety of meanings. The Latin 'liber' refers to a class of freeman. It has meant 'generous' as in liberal helpings of food and drink. In reference to social attitudes it has implied openness or open mindedness. It has also come to be increasingly associated with ideas of freedom and choice (Heywood 1997).

Liberalism was the first modern political ideology to emerge and the only one that was part of the great transition from medieval to modern times. This transition took several centuries and involved a whole series of revolutions and developments including the Renaissance, the Protestant Reformation, the rise of capitalist enterprise and of sovereign nation-states and the development of modern science (Adams 1998: 12).

Politically, liberalism was later developed in the context of the eighteenth century Enlightenment. Enlightenment philosophers such as John Locke (1632-1704) engaged in a philosophical critique of absolutism. The doctrine of divine right was 
incompatible with the rise of the bourgeoisie who had to be 'free' from feudal authority. From this basic drive for power developed the political theory of liberalism and the bourgeois ideological concept of freedom, in opposition to medieval absolutism (McNair 1999: 30). Locke had a different conception of liberal components such as rationality or human progress than later liberals (Freeden 1996: 141). In terms of religion, as McManners comments,

\begin{abstract}
The two centuries preceding the French revolution were marked by the growing secularization of West European society, culture, and thought... It is reasonable to say that a Christian civilization had arisen ahead of all possible processes of individual conversion, and in its shelter, human individuality and freedom had been evolving. Religion was on its way to becoming a matter of intense personal decision...European life was being secularized; religion was becoming personalized, individualized: the two things went together, and were interdependent (1990: 267).
\end{abstract}

Therefore, I regard liberalism as originating from the struggle for freedom between individuals and religion (not freedom from religion as some atheists argue).

In the nineteenth century, the French revolution truly acted as a watershed for European political thought. As Karl Mannheim noted, 'Any study in styles of thought characteristic of the first half of the nineteenth century must start with the fact that the French Revolution acted as a catalyzing agent [...]' (1971: 135, cf. Kahan 2003: 16). The nineteenth century became the era of liberalism which fused Enlightenment and romantic elements.

\title{
The Fundamental Values of Liberalism
}

Liberalism places fundamental concepts such as liberty and equality at its centre. There is widespread acceptance of the individual as the basic social unit of liberalism (Avnon and de-Shalit 1999: 2). Liberal theories can be applied to human interaction to capture the richness of human behaviour and its sophistication. The absoluteness of individuality as a core liberal concept is narrow.

As Strauss puts it

liberal education is the ladder by which we try to ascend from mass democracy to democracy as originally meant; it is the essential endeavour to found an aristocracy within the democratic mass society and it reminds those members of a mass democracy who have ears to hear of human greatness (1968: 5).

In both the historical and ontological roots of liberalism, there is a desire to live in social and political contexts that acknowledge, respect and even foster a person's inner complexity and creativity (Avnon and de-Shalit 1999: 3). John Stuart Mill (1806-1873) resolves the conflict between liberty and utility by asserting that individuals' true freedom inheres in maximising their utility. Self-cultivation and self- 
development are important concepts in Mill's liberal ideas: '[...] by cultivating individual within the limits imposed by the rights and interests of others, human beings become a noble and beautiful object of contemplation' (Mill 1991: 70). Mill further asserts that 'Individuality is the same thing with development, and that it is only the cultivation of individuality which produces, or can produce, well-developed human beings [...]' (ibid: 71), and that 'The spirit of liberty is the source of progress or improvement' (ibid: 78).

Thomas Hill Green (1836-1882) notes that human beings have a capacity to evaluate desires which is in turn related to their power of self-evaluation (cf. Bellamy 2000: 34). He states that morality and freedom are inextricably linked. Virtue implies the ability to freely choose to behave morally, thus Green's theory makes the social and moral basis of freedom explicit, thereby providing liberalism with more solid foundations (ibid: 22). Green argues that self-realisation and the pursuit of selfperfection can only take place in a social context since the 'individual always needs a society to make the conscience for him' (Green 1986: 293).

Georg Wilhelm Friedrich Hegel (1770-1831) is charged with substituting the plurality and freedom of society for the imposed uniformity of a preconceived metaphysical entity, the 'supra-individual' state (cf. Bellamy 2000: 3). Bellamy does not regard Hegel's political theory as totally antithetical to liberalism. In fact, Hegel's concepts of Geist (spirit) and Sittlichkeit (ethical life) function in support of his ontological analysis of human existence. Bellamy writes that 'This theory completes, rather than undermines many central liberal claims regarding the primacy of the individual in the social process' (Bellamy 2000: 3). More specifically, Hegel invokes a universal element to mediate between the particularity of our wants and needs, and the individuality of the subjective will. This is supplied by his concept of Geist. Every community has a characteristic set of cultural norms and values inherent in the collective practices of its members, a Volksgeist. The individual shares many of the concepts of his fellows as 'a form of necessity' by virtue of the normal processes of socialisation. However, this does not entail the complete identification of individual and social context; 'for this consciousness emanates from the individual himself and is not instilled into him by others: the individual exists within the substance' (Hegel 1975: 52). Hegel views liberalism as a complex of selfunderstandings, orientated around the pursuit of the common good. Thus communitarianism is not opposed to liberalism. It is a fact that communitarianism has been accommodated within liberalism (Freeden 1996: 248).

\section{New Liberalism}

The new generation of liberal thinkers succeeding Mill and Green etc. demonstrated an explicit social and cultural reaction to the industrial revolution which accommo- 
dated the ascendant working class, namely New Liberalism (Freeden 1996: 194). Leonard Trelawny Hobhouse's (1864-1929) Liberalism, published in 1911, marked this evolution of liberalism - the revised liberal ideology. Hobhouse derived from Mill a notion of self-development of personality, an understanding of liberty as a process of growth, and a sense of the mutual compatibility between individual and social well-being (Freeden 1996: 196). He claims that 'only when a man is controlled by principles and rules which all society must obey, for the community is the true master of the free man' (Hobhouse 1911: 27). His liberal position is described as follows: 'We have, in fact, arrived by a path of our own at that which is ordinarily described as the organic conception of the relation between the individual and society' (ibid: 136) (cf. Freeden 1996: 196). He appealed to the ideal society as a whole which lives and flourishes by the harmonious growth of its parts (ibid: 137). Hobhouse noted the habitual association of liberty and equality and qualified this link in two ways. First, he made it clear that liberty implies equality. Second, he made the link dependent on more exact definitions of liberty and equality. This influenced twentieth-century liberal thinkers and co-opted equality into the liberal core (Freeden 1996: 196).

\section{Liberalism and the Media}

The ideology of liberalism is indispensable in the media. The invention of printing - which represented the birth of mass communication-coincided with the birth of liberalism (McNair 1999: 28). John Milton (1608-1674) articulated the concept of press freedom as early as 1644, and pioneered the concept of 'the open market of ideas' (Milton 1940). Applied to the media, liberal principles meant the free competition of ideas and opinions between diverse viewpoints. These principles remain fundamental to the working of liberal democratic societies. Tolerance and diversity continue to be regarded as essential for servicing a democratic political system, enlightening and informing the public, and allowing the media to prevent dictatorship (McNair 1999: 30). John Keane argues that

the call for press freedom is a distinctive organizing principle of the modern European and North American worlds...the theory and practice of publicly articulating opinions through the media of communication developed endogenously in no other civilization (1991: 7).

Nevertheless, the principle of liberalism in the media does not mean that one can report without considering collective values. ${ }^{8}$

8 For example, BBC broadcaster Jeremy Clarkson commented that public sector workers should be shot dead in front of their families on The One Show on November 30, 2011. Though intended to be comic, his comments caused outrage. This case demonstrates that 'collective values and ethics' count in a 'liberal' British media. 


\section{Liberalism and Democracy}

Liberalism itself is not monolithic: there is variety within the basic framework. Liberalism as a discourse about public capacities, not private rights, is not consonant with modern democratic freedom. This gives precedence to the private over the public and denies that public life has any autonomous existence except as a means of guaranteeing private freedom. Democratic political language embraces the civil rights aspect of liberalism and rejects the discourse of capacity. It argues that the only way to guarantee private rights is to extend to public life the formal equality that private rights entail (Kahan 2003: 191). Politically, a democratic liberalism aims at compromises through the expression and discussion of controversial views (Bellamy 2000: xiii). In this sense, liberalism is in agreement with, rather than contradictory to, harmony as discussed above.

\section{Reconciliation of Harmony and Liberalism in Contemporary China}

Harmony, as the highest good in the persistent traits of classic Confucianism, NeoConfucianism and New Confucianism, refers to the perfection of human nature. Liberalism - whether classical liberalism, reformist liberalism, new liberalism or philosophical liberalism - has liberty as its core concept. This section intends to accommodate liberalism and harmony in a Chinese context.

As discussed above, we must be aware that harmony is the ideal internal human state. Externally, as an ideal of social life, harmony attempts to ameliorate conflicts, and therefore to achieve a peaceful social order. In practical terms, harmony is an attempt to seek common ground for different opinions, commitments, and ideological orientations ( $\mathrm{Tu}$ 2012: 78). Harmony presupposes diversity and celebrates difference (ibid). In fact, a perfectly harmonious common good and collective value system is an unrealised ideal. Harmony cannot be actualised as uniformity, for then it could be used as a tool of despotism. An oppressed 'self', an unvoiced 'self' or an enslaved 'self' completely subordinated to collective value (radical harmony) cannot pursue self-development.

Therefore in contemporary China, reform in political policy should firstly concentrate on personal moral reconstruction, i.e. it should emphasise moral selfcultivation. Mencius stresses a regimen for self-improvement that allows the person to be of service to the larger community. For him, self-cultivation is not merely a private enterprise but a public necessity (Berthrong 1998: 23). The central tenet of the Dàxué is developing self-cultivation to achieve harmony. As it claims, 'from the king 
down to the common people, all must regard the cultivation of the self as the most essential thing' (the Dàxué). ${ }^{9}$

At present, Chinese individuals' moral sensibilities are distorted and have weakened the collective structures of Chinese society. Market-based system has proved a successful model for Chinese economic development (according to the increasing GDP). However, during the application of this model, the imbalance between morality and materiality has been radical, and maximisation of profiteering has led to the marginalisation of justice as reflected in, for example, the deplorable state of food safety and environmental destruction. This, in fact, has become the biggest barrier for further progress for the community. Under these conditions, the important moral cultivation that individuals must perform, expressed philosophically, is 'thinking of others' as a means of achieving harmonious relations. For Confucians the selfish rush for material self-interest is powerfully corrosive to social bonds and affections. When being materialistic, an individual is easily lost in consuming desires - sexual desires, material desires, the desire for power, etc.- - hence the contemporary moral crisis. The warning of the Confucians is anachronistic in today's China, where humanity and duty are swamped by conspicuous profit.

'Self-cultivation' lies in individual liberty, the core concept of liberalism. Tolerance to liberty of thought forms the social morality of a nation. Self-realisation helps an effective self-cultivation. Individual liberty encourages active individual participation in the collective good. Classic Confucianism teaches that harmony is the most excellent functioning of heaven which enables humans to flourish. In the Analects, a profound person agrees with what is good and does not merely echo or accommodate the thoughts of others (hé ěr bù tóng 和而不同) (Berthrong 1998: 191). Freedom of thought is highly important with regards to achieving harmony. Liberal principles encourage the free exchange of ideas and opinions from diverse viewpoints. Tolerance and diversity are regarded as essential to freedom of thought (McNair 1999: 30).

The successor of Locke, Mill's (1869) core concepts of liberalism are 'good', which refers to 'the highest and most harmonious development' (Freeden 1996: 147) of individual powers, and 'liberty,' i.e. self-development. Communitarianism has also been accommodated within liberalism (ibid: 248). Any given community has a set of cultural norms and values inherent in the collective practices of its members. The individual shares the concepts of his fellows by virtue of the normal processes of socialisation (Hegel 1975: 52).

As outlined above, Confucius stated that the propagation of a peaceful and harmonious life was guaranteed by virtue (dé 德). Liberal philosopher Green states that morality and freedom are inextricably linked. Virtue implies the ability to act in

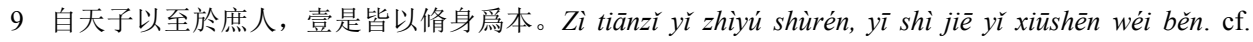
http://www.acmuller.net/con-dao/greatlearning.html; accessed July 5, 2012. 
an un-coerced manner, to freely choose to behave morally (Bellamy 2000: 35).The notion of humaneness (rén 仁) in Confucianism is similar to aspects of liberal human rights, which express the value of impartial concern to relieve human suffering. Any humanist society should have human rights as its centre.

Twentieth-century liberal thinkers co-opted equality into the liberal core (Freeden 1996: 243). Equal human freedom is innate to human beings, and they cannot be deprived of it. Liberty is the prerequisite for the wealth of nations. As a source of progress and wealth, freedom appears to be inexhaustible (Dietze 1985: 219). The application of equality should be a principle feature of a harmonious society, whilst an emphasis on the restriction of liberty, i.e., the need for material development becomes a question of morality. It emphasises spiritual cultivation in order to encourage the moral activities of individuals and to promote the value of a responsible self.

Harmony provides an ideal relationship (guānxì 关系) either with people, nature or heaven. Desire of culture of relationship (guānxì wénhuà 关系文化) to harmony which is congenial to achieve solidarity rather than struggle is one value of Confucianism. This point distinguishes Eastern liberalism from Western liberalism. Individuals cannot get actual liberty if they do not achieve a harmonious relationship in all spheres of life. The advocacy of harmony of liberty in a Chinese context has a long way to go. Chinese academia and New Confucians should strive harder to apply the value of liberalism to self-cultivation, thus discovering the right relationship between liberty and harmony in a Chinese context. However, harmony does not mean blind conformity to collective viewpoints, while liberalism does not equal individual autonomy: community is a necessity. In short, there is no cause to debate which is a more progressive ideology_liberalism or harmony - but rather there is an urgent need to restore morality for the establishment of a harmonious society which encourages freedom of thought and celebrates diversity.

\section{Concluding Remarks}

We have to admit that the similarities between liberalism and harmony have been ignored in many areas in modern history - in common perception, philosophical studies, cultural theory, political philosophy, historical theory, and so forth. People are more interested in exploring their differences than their similarities, as if entirely rejecting another viewpoint is the way to guarantee one's own survival. Because they do not 'look' like each other, this leads to endless disputes about what the differences are and why the differences exist. In this sense, incompatibility between liberalism and harmony is already presupposed based on stereotyped 'contrasting differences'. 
Despite their quintessential similarities, liberalism and harmony are still different, at least in practice in different social contexts. We must confront the fact of 'human diversity in multiple diverse forms,' and hence the fact that 'there is a growing need to go beyond mere tolerance of difference to an appreciation and celebration of it' (Keenan 2011: x). Finding a common ground between liberalism and harmony in this paper, in fact, is an application of theory to practice in order to 'appreciate and celebrate' these two superficially conflicting ideologies. A lack of understanding of these shared foundations may have been the deep-rooted cause and instigator of clashes between the East and the West. This matters, because if we cannot find common ground for liberalism and harmony, then the contradictions and clashes will persist and keep on breaking out in many different situations.

The common ground between harmony and liberalism continues to fluctuate in modern times. Up to now these principles have not been reconciled, even though there is more synthesis between the East and the West in a 'smaller' world. In modern China, the revival of Confucian harmony and the development of liberalism may become allied in a progressive reformation of moral virtues. The challenge to their future lies in their efforts to co-exist and balance each other out. Confucianism is in radical transformation both in its homeland in China and in its reach internationally. The critiques in this paper may contribute to a more applicable harmony in contemporary China. 


\section{REFERENCES}

Adams, Ian. Ideology and Politics in Britain Today. Manchester and New York: Manchester University Press, 1998

Angle, Stephen C. Contemporary Confucian Political Philosophy. Cambridge, UK: Polity Press, 2012

Avnon, Dan and Avner de-Shalit. "Introduction: Liberalism between Promise and Practice". In Liberalism and its Practice, edited by Dan Avnon and Avner de-Shalit. London and New York: Routledge, 1999, pp. 1-15

Bellamy, Richard. Rethinking Liberalism. London: Continuum International Publishing, 2000

Berthrong, John H. Transformations of the Confucian Way. Boulder: Westview Press, 1998

Chilton, Paul, Hailong Tian, and Ruth Wodak."Reflections on Discourse and Critique in China and the West." In Journal of Language and Politics, 9/4, 2010, pp. 489-507

Dietze, Gottfried. Liberalism Proper and Proper Liberalism. Baltimore: The Johns Hopkins University Press, 1985

Fan, Ruiping. Confucian Bioethics. Hingham, USA: Kluwer Academic Publishers, 1999

Fang, Keli and Jinquan Li. Contemporary New Confucianism. Beijing: China Social Sciences Press, 1995

Freeden, Michael. Ideologies and Political Theory: A Conceptual Approach. Oxford: Oxford University Press, 1996

Freeden, Michael. Ideology: A Very Short Introduction. Oxford: Oxford University Press, 2003

Hegel, Georg Wilhelm Friedrich. Lectures on the Philosophy of World History: Introduction, trans. H. B. Nisbet, Cambridge: Cambridge University Press, 1975

Heywood, Andrew. Politics. London: Macmillan, 1997

Hobhouse, Leonard Trelawny. Liberalism, London: Oxford University Press, 1911

Green, Thomas Hill. Lectures on the Principles of Political Obligation. Cambridge: Cambridge University Press, 1986

Jiang, Qing. "From Mind Confucianism to Political Confucianism". In The Renaissance of Confucianism in Contemporary China, edited by Ruiping Fan. Dordrecht: Springer, 2011, pp. 17-32

Kahan, Alan. Liberalism in Nineteenth-century Europe: The Political Culture of Limited Suffrage. Gordonsville: Palgrave Macmillan, 2003

Keane, John. The Media and Democracy. Oxford: Polity Press, 1991

Keenan, Barry. C. Neo-Confucian Self-Cultivation. Honolulu: University of Hawai'i Press, 2011

Kleeman, Terry. "Daoism and the Quest for Order." In Daoism and Ecology, edited by Norman J. Girardot, James Miller, and Liu Xiaogan. Cambridge: Harvard University Press, 2001, pp. 6169

Kohn, Livia. "Change Starts Small: Daoist Practice and the Ecology of Individual Lives." In Daoism and Ecology, edited by Norman J. Girardot, James Miller, and Liu Xiaogan. Cambridge: Harvard University Press, 2001, pp. 373-390

Lai, Chi-Tim. "The Daoist Concept of Central Harmony in the Scripture of Great Peace: Human Responsibility for the Maladies of Nature." In Daoism and Ecology, edited by Norman J. Girardot, James Miller, and Liu Xiaogan. Cambridge: Harvard University Press, 2001, pp. $95-$ 111

Li, Huawei. Rural Christians and Confucian Ethics: A Case on Church of Li Village. Beijing: Social Sciences Academic Press, 2013

Littlejohn, Ronnie. L. Confucianism: An Introduction. London: I. B. Tauris, 2011

Locke, John. Two Treatises of Government. London: The McMaster University Archive of the History of Economic Thought, 1823 
Louden, Robert. B. “'What does Heaven Say?' Christian Wolff and Western Interpretations of Confucian Ethics." In Confucius and the Analects: New Essays, edited by Bryan W. van Norden. New York: Oxford University Press, 2002, pp. 73-93

Luo, Jialing. "“Betwixt and Between': Reflections on the Ritual Aspects of the Opening and Closing Ceremonies of the Beijing Olympics.” In Sport in Society, 13/5, 2010, pp. 771-783

Makeham, John. New Confucianism: A Critical Examination. New York: Palgrave Macmillan, 2003

McManners, John. History of Christianity. Oxford: Oxford University Press, 1990

McNair, Brian. News and Journalism in the U.K.: A Textbook. London and New York: Routledge, 1999

Mill, John Stuart. On Liberty and Other Essays. Oxford and New York: Oxford University Press, 1991[1869]

Milton, John. Areopagitica. Cambridge: Cambridge University Press, 1940

Moeller, Hans-Georg. Philosophy of the Daodejing. New York: Columbia University Press, 2006

Reid, Heather and Christos C.Evangeliou. "East to Olympia: Recentering Olympic Philosophy between East and West". In Pathways: Critiques and Discourse in Olympic Research, edited by Robert K. Barney, Michael K. Heine, Kevin B. Wamsley, and Gordon H. MacDonald. Ninth International Symposium for Olympic Research. London, Ontario: The International Centre for Olympic Studies, 2008, pp. 338-50

Strauss, Leo. Liberalism: Ancient and Modern. New York and London: Basic Books, 1968

Tu, Weiming. "Confucian Spirituality in Contemporary China." In Confucianism and Spiritual Traditions in Modern China and Beyond, edited by Fenggang Yang and Joseph B. Tamney. Leiden: Brill, 2012, pp. 75-96

van Norden, Bryan W. Confucius and the Analects: New Essays. New York: Oxford University Press, 2002

Wang, Ruichang. "The Rise of Political Confucianism in Contemporary China." In The Renaissance of Confucianism in Contemporary China, edited by Fan, Ruiping. Dordrecht: Springer, 2011, pp. 33-45

Yao, Xinzhong. Introduction to Confucianism. Cambridge: Cambridge University Press, 2000

Zeng Zi. The Great Learning. Translated by A. Charles Muller, 2010, http://www.acmuller.net/ con-dao/greatlearning.html, accessed July 2012 


\section{GLOSSARY}

\begin{tabular}{|c|c|c|}
\hline Chéng Hào & 程影 & Neo-Confucian (1032-1085) \\
\hline Chéng Yí & 程頣 & Neo-Confucian (1033-1107) \\
\hline dào & 道 & $\begin{array}{l}\text { the 'Way', traditional Chinese } \\
\text { philosopheme }\end{array}$ \\
\hline$d e ́$ & 德 & virtue \\
\hline Dàodéjīng & 道德經 & the ancient Daoist classic \\
\hline Dàxué & 大學 & the Great Learning \\
\hline guānxì & 关系 ～～～～～～～～～ & relationship \\
\hline guānxì wénhuà & 关系文化 & culture of relationship \\
\hline Hàn cháo & 漢朝 & Hàn Dynasty (206 BCE-220 CE) \\
\hline hé & 和 & harmony \\
\hline hé èr bù tóng & 和而不同 & $\begin{array}{l}\text { Confucian rhetoric of harmonious } \\
\text { but different }\end{array}$ \\
\hline héxié shèhui & 和諧社會 & harmonious society \\
\hline héxié shìiè & 和諧世界 & harmonious world \\
\hline huŏ & 火 & fire \\
\hline Jiăng Qìng & 蔣慶 & new Confucian (b. 1953) \\
\hline jīn & 金 & metal \\
\hline Kāng Xiăoguāng & 康曉光 & new Confucian (b. 1963) \\
\hline Kǒngzĭ & 孔子 & Confucius (tr. 551-479 BCE) \\
\hline Liáng Shùmíng & 梁漱溟 & New Confucian (1893-1988) \\
\hline Lǐxué & 理學 & School of Principle \\
\hline Lúnyǔ & 論語 & $\begin{array}{l}\text { Analects, a collection of sayings, } \\
\text { brief discussions and observations } \\
\text { by and about Confucius, his disci- } \\
\text { ples and his contemporaries }\end{array}$ \\
\hline mínběn & 民本 & $\begin{array}{l}\text { the people are of supreme } \\
\text { importance }\end{array}$ \\
\hline ming & 命 & to rule \\
\hline Móu Zōngsān & 牟宗三 & new Confucian (1909-1995) \\
\hline$m \grave{u}$ & 木 & wood \\
\hline$q \grave{\imath}$ & 氣 & $\begin{array}{l}\text { a sort of general or universal } \\
\text { 'medium'-it is not only in 'nature' } \\
\text { but also in works of art, houses and } \\
\text { gardens, interpersonal relations and } \\
\text { emotions }\end{array}$ \\
\hline Qīng & 清 & $\begin{array}{l}\text { Qing Dynasty (1644-1912), the last } \\
\text { feudal dynasty in China }\end{array}$ \\
\hline rén & 仁 & humaneness \\
\hline Shāng & 商 & $\begin{array}{l}\text { Shāng Dynasty (tr. 1600-1046 } \\
\text { BCE) }\end{array}$ \\
\hline $\begin{array}{l}\text { shèhuì zhǔyì héxīn } \\
\text { jiàzhíguān }\end{array}$ & 社会主义核心价值观 & the core socialist values \\
\hline shǔi & 水 & water \\
\hline Sòng cháo & 宋朝 & Sòng Dynasty (960-1279) \\
\hline
\end{tabular}


tàijí

tiān

tiānxià yījiā

tǔ

Wáng Shǒurén

Xí Jìnpíng

xīnhài gémìng

Xīnxué

Xióng Shílì

Xúnž̌

yīn-yáng

zhōngguó mèng

Zhōngyōng

Zhōu

Zhōu Gōng

Zhòu

Zhū Xī
太極

天

天下一家

土

王守仁

习近平

辛亥革命

心學

熊十力

荷子

陰/陽

中国梦

中庸

周

周公

紂

朱喜 the ancient Chinese diagram of yin and yáng, shows the two fundamental energy forces at the root of the universe in interlocking harmony heaven

the unity and harmony of all-underheaven

earth

Neo-Confucian (1472-1528)

Chairman of the People's Republic of China (b. 1953)

the Xīnhài Revolution

School of Mind

New Confucian (1885-1968)

Confucian (tr. 371-289 BCE)

during the Warring States period

in Chinese creation myth, the dào gave birth to the One, which is divided into two opposing entities, $y \overline{i n}$ and yáng. The two produce three energies, harmonious, pure, and turbid, which go on to form the triad Heaven, Earth and Man. These three forces join in producing the myriad things. The viability of life depends upon the mutual harmony of the yinyáng polarity of all things

China Dream

the Doctrine of the Mean

Zhōu Dynasty (tr. 1046-256 BCE)

Duke of Zhou (tr. 1100 BCE-?), known as the First Sage (Yuán Shèng 元聖)

the last Shāng King(tr. 1105-1046

$\mathrm{BCE}$ )

Neo-Confucian (1130-1200) 